\title{
Naiv szemantika
}

\author{
Kálmán László \\ MTA Nyelvtudományi Intézet \\ MTA-ELTE Elméleti Nyelvészet Kihelyezett Tanszék
}

\begin{abstract}
Összefoglaló
A szerző amellett érvel, hogy a poszt-generatív nyelvészeti iskolák nagy részére (amelyeket összefoglaló néven „naiv nyelvtannak” nevez) az a vonás jellemző, hogy nem törekszenek arra, hogy a lehető legáltalánosabb formában fogalmazzák meg a szabályszerüségeket, és inkább hosszabb, bonyolultabb levezetéseket használjanak arra, hogy ezekből a konkrét jelenségeket levezessék. A cikk ennek az újdonságnak, különbségnek elsősorban azokra a következményeire összpontosít, amelyek a szorosabb értelemben vett nyelvtan és a jelentéstan kapcsolatát (így pl. az ún. kompozicionalitás elvét) érintik.
\end{abstract}

Kulcsszavak: nyelvtanelmélet, szemantika, használatalapú nyelvtan, konstrukciós nyelvtan, kompozicionalitás

\section{Bevezetés}

Több mint negyven éve jelent meg „A naiv fizika kiáltványa” (The Naive Physics Manifesto: Hayes (1979)). Ennek a lényege az volt, hogy az embereknek a külvilágról szóló hétköznapi („naiv”) tudása nem olyan felépítésű, mint a tudományos elméletek. Míg a tudományos elméletek maximális általánosságra törekszenek, a lehető legáltalánosabban próbálják megfogalmazni a megfigyelt törvényszerűségeket, egy minimális méretű axiómarendszerből vezetik le tételekként az állításaikat (gyakran nagyon hosszú levezetések segítségével), a hétköznapi gondolkodásban nagyon nagy axiómarendszert és kevés következtetést kell feltételeznünk.

Írásom fő álítása az, hogy a természetes nyelv ismerete ebben a vonatkozásban a hétköznapi ontológiához és metafizikához hasonlít. Nemcsak semmi szükség maximális általánosságra és minimális axiómarendszerre, hanem kifejezetten csak úgy tudjuk hüen megragadni a nyelvi képességeket, ha nagy memorizált tudásbázist feltételezünk, és kevés levezetést.

A következőkben először (2. pont) magát a problémát ismertetem, néhány bonyolult problémakör felületes felvillantásával illusztrálva. A 3. pontban egy sokkal egyszerübb, de konkrétabb példán (a magyar mutató névmás két használatán) mutatom be, hogy pontosan miért vall kudarcot a maximális általánosítás alapelve. A 4. pontban egy olyan példát vizsgálok meg, amiben már nem egyetlen lexikai elemnek, hanem egész szerkezeteknek a többféle használata áll a középpontban. Ehhez kapcsolódva az 5. pontban amellett érvelek, hogy az érvelésem értelmében a kompozicionalitás alapelvét a szokásostól eltérően is lehet, sőt szerintem kell is értelmezni. 


\section{A maximális általánosság kudarca}

Óriási szakirodalma van annak, hogy némelyik természetes nyelvi kifejezés változatos használatait hogyan lehet valamilyen egységes, nagyon általános „jelentésből” levezetni. Végülis érthető ez az igyekezet. Egyrészt az emberi kultúrában (legalábbis az európaiban) mélyen gyökerezik az az elképzelés, hogy a gondolataink ún. „fogalmakba” rendeződnek, és a nyelvi kifejezések ilyen fogalmakat jelölnek, valamint hogy van a kifejezéseknek valamilyen inherens tulajdonságuk (ezt szokták „jelentésnek” nevezni), ami magyarázatot ad arra, hogy a legkülönbözőbb körülmények között hogyan értelmezzük őket. (Az ókor óta ennek fő filozófiai forrása Arisztotelész (1979), a modern korban pedig Frege (1892).) Másrészt azért is érthető ez a próbálkozás, mert - a nyilvánvaló homonímia, véletlen egybeesés eseteit leszámítva - ugyanannak a kifejezésnek a sokféle használatát valami motiválni szokta, sokszor történetileg is ki lehet mutatni, hogy ezek az eltérő használatok milyen közbeeső (esetleg azóta eltűnt) értelmezéseken keresztül alakultak ki korábbiakból, esetleg teljesen „logikus” jelentésváltozási lépésekben (vö. Paul 1886). Végül az a nézet is igen elterjedt (különösen Chomsky (1957) óta, aki az uralkodó természettudományos paradigma mintájára próbálta átformálni a nyelvészetet), hogy a kevés, nagyon általános axióma és a sok tétel (amiket elvileg szintén elég általános szabályok ismételt alkalmazásával „gyárthatunk le”) egyszerübb leírását adja a jelenségeknek, mint ha nagyon sok partikuláris, másból nem levezethető jelenség létezését feltételezzük. Anélkül, hogy vitatnám, hogy azonos jelenségeket leírni képes elméletek közül az egyszerübbet kell választanunk (vö. Friedman 1974), felhívom a figyelmet arra, hogy a nyelvészeten belül egy leírás globális egyszerüségének mérésére még soha semmilyen komolyan vehető javaslat nem született.

De az, hogy megértőek vagyunk ezzel a megközelítéssel, nem kell hogy azt jelentse, hogy egyet is értünk vele. Attól, hogy egy felfogás kulturálisan jól be van ágyazva, és még mindenféle érthető motivációval is rendelkezik, még lehet teljesen téves vagy célszerütlen a tudományos leírás szempontjából. Szerintem itt is erről van szó.

Ennek belátásához elég felületesen belegondolni néhány példába. Rengeteget foglalkoztak például azzal, hogy minek köszönhető az olyan szavaknak, mint már (angolul: yet, already, again stb.), még (angolul: yet, still, even, already, more stb.) vagy is (angolul: also, too, even, again stb.), a rengetegféle használata (I. pl. Krifka 2000; Zimmermann 2018). Mint az angol fordításokon is látszik, még átfedések is vannak a használataik között, ugyanakkor szinte minden típusú szerkezetben, amiben előfordulnak (különböző típusú állítások, fókusz, mindenféle kérdések, tagadó szerkezetek) más-más az értelmezésük (és más nyelvekre is más-más módon kell őket fordítani), viszont azt aligha érdemes feltételezni, hogy homonímia áll fenn közöttük.

Például a már szót használjuk mindenféle időbeli viszonyok jelölésére, meg a referenciaidőben elhelyezett események folytatására vonatkozó elvárások érzékeltetésére: Megnézted már [ahogy várható volt vagy ígérted vagy megbeszéltük]? Meg még sok minden másra, például kérdések bevezetésére (pl. Már miért mennék el az előadására?). A még szónak szintén van időviszonyokkal kapcsolatos használata, de ilyenkor egyúttal valamilyen elvárásokra is utalni szokott (pl. Még nem feküdt le vele [pedig számítani lehetett volna rá]). Ugyanakkor például a 'többet, 
továbbra is' értelmezésében (pl. Hugó kér még a sütiből) sem az időbeli, sem az elvárásbeli asszociációi nincsenek jelen, bár valami halvány motivációt talán érezhetünk abban, hogy mindkét esetben ugyanazt a szót használjuk. Az is szó a szinte kötőszó-szerü használatában olyasmit fejez ki, mint a 'szintén', de a még ... is alakú szerkezetben való használatának ehhez csak távoli asszociáció révén van köze, nem is beszélve például arról a használatáról, amikor olyasmit fejez ki, hogy 'nemcsak egy említett gyengébb, hanem egy erősebb állítást is tehetünk', pl. Be akart lépni, és végül be is lépett.

Szerintem ebből a néhány kiragadott példából is világosan látszik, hogy teljesen lehetetlennek látom egyetlen nagyon általános „,jelentésből” levezetni az ilyesféle szavak rengeteg lehetséges használatát. Ez felelne meg a bevezetőben említett maximális általánosság kritériumának: minél kevesebb jelenséget tekintsünk „véletlennek”, külön axiómaként kimondandónak, minél többet vezessünk le nagyon általános axiómákból. A szavak esetében ez azt jelenti, hogy a szó minden egyes használatát a nagyon általános ,jelentéséből” kell levezetni. Az ilyen próbálkozások részben elképesztő mértékben túlgenerálnak, vagyis az alapjelentés túl általános volta miatt hamis jóslatokat tesznek arról, hogy mikor használják a beszélők az érintett szavakat, részben, ha ezt el tudják kerülni, annyiféle speciális tulajdonságot kell feltételezniük az érintett sokféle szerkezetről, amik mellett nem tudnak független érveket felhozni. Ráadásul az egész apparátus, amire ezekhez a „magyarázatokhoz” szükség van, végső soron valószínüleg sokkal bonyolultabb, mint ha eleve nem feltételeznék, hogy az illető szavaknak van egy-egy nagyon általános „,jelentésük”.

Könnyen belátható, hogy ez a probléma nemcsak az olyan „üres” szócskák esetében áll fenn, mint a már vagy a még. Például ha a lehető legáltalánosabban akarjuk meghatározni a kert főnév vagy a tol ige „jelentését”, úgy, hogy a meghatározások minden előforduló használatukat lefedjék, akkor olyan általános definíciókat kellene adnunk (pl. „valamilyen határokkal rendelkező alig beépített földterület”, illetve „valamire erőt gyakorol, általában azzal az eredménnyel, hogy azt elmozdítja”), amiből az a jóslat adódna, hogy az emberek rengeteg mindenre mondanák, hogy kert vagy tol, olyanokra is, amikre a valóságban nem. (Például nagyon sok park, tér stb. van, amit senki sem hívna kertnek, és senki se mondaná a csengő megnyomását tolásnak.) A fenti eseteket, mind a határozószócskákat, mind pedig a kert és a tol szavakat csak példaként említettem. Részletes vizsgálatuk nyilván túllépné ennek a cikknek a kereteit. Ezért a következő alpontban csak egy egyszerübb példán próbálom részletesebben bemutatni a maximális általánosításon alapuló elemzés nehézségeit.

\section{Egy egyszerübb eset: a mutató névmás határozottsága}

Én először Simonyinál szembesültem azzal az érdekes ténnyel, hogy a magyarban az ez, az mutató névmás nemcsak határozott lehet: „PI. azt veszem meg (ellenben: azt veszek nem az egyénre, hanem csak a fajra mutat, a. m. abból veszek, affélét veszek)" (Simonyi 1905 [1889]: 450). A homonímián alapuló elemzést nyilván elvethetjük, hiszen az ez, az mindkét használatában nagyjából ugyanaz a (közelre, illetve távolra) mutató mozzanat az uralkodó, és ezt nagyon nehéz lenne megmagyarázni, ha csak véletlen egybeesést feltételeznénk. Az a kérdés, hogy ha nem homonímiáról van szó, akkor milyen leírást választhatunk. 
Ha a maximális általánosság stratégiáját akarjuk követni, akkor vagy olyasmit kell mondanunk, hogy az ez, az szavakat egyáltalán nem jellemezzük határozottság (illetve individuumra való utalás) szempontjából, vagy pedig az egyik használatot (valószínúleg a fajtára utalást) általánosabbnak kell tekintenünk, és a másikat úgy kell ebből levezetnünk, mint specializált, gazdagított „,jelentést”. A probléma az, hogy egyik megoldásra sincs más bizonyítékunk, mint maga az a szerkezet, amit Simonyi felfedezett, és emiatt az elemzésünk függetlenül nem alátámasztható, ad hoc jellegü lesz.

Egyedül talán a névszói álítmány névszói részét játszó mutató névmás mutat némi rokonságot a Simonyi-féle szerkezetben megfigyelhető értelmezéssel: - Alelnök volt? - Az (volt). Csakhogy ebben a szerkezetben csak a távolra mutató az jelenhet meg (ezért talán nem is tekinthetjük mutató névmásnak, ahogy például az utalószót sem szoktuk annak tekinteni): - Alelnök volt? - *Ez (volt). És ez nemcsak válaszmondatokra igaz: nem mondjuk azt, egy böröndre mutatva, hogy Ez/az a böröndöm vagy $A z$ én böröndöm is ez/az, ha azt akarjuk mondani, hogy 'pont ilyen/olyan fajta bőröndöm van nekem is'.

Általában nem működik a Simonyi-féle magyarázat, hogy az általa idézett példában az ez, az nem individuumra, hanem fajtára utal, nem ad számot a határozatlanságáról (amit az bizonyít, hogy ha tárgy, akkor alanyi ragozású igét használunk mellette). Mert igaz, hogy a Simonyi-féle határozatlan szerkezetekben a mutató névmásoknak 'ilyet/olyat, effélét/affélét' az értelmezése, de szó sincs arról, hogy mindig ilyen jelentésű kifejezésekkel helyettesíthető. Mert például az ezt/azt a fajtát kifejezést tapasztalatom szerint nem használják alanyi ragozású igelakokkal a magyar beszélök.

A Simonyi által adott másik parafrázis, a partitívusz jellegü (azt veszek 'abból veszek') már sokkal meggyőzőbb, mert természetesen alanyi ragozású igével állhatnak az olyan kifejezések, mint ebból/abból a fajtából. Csakhogy ezzel meg az a probléma, hogy magyarázatnak ez is sovány, mert semmilyen (a Simonyi-féle példáktól) független bizonyítékunk nincs arra, hogy a mutató névmásoknak, vagy különösen úgy általában a határozott névszói szerkezeteknek partitívuszi értelmezése is lehetne a magyarban. Nem mondunk például olyanokat, hogy * $A$ böröndöt kérek (abban a szándékolt értelemben sem, hogy 'a bőröndök közül kérek valamennyit'). Ráadásul - és erre ennek az írásnak a névtelen bírálója hívta fel a figyelmemet - a partitívuszos értelmezés nehezen fér össze azokkal az esetekkel, amikor az ez/az előzménye komplex névszói szerkezet, pl. - Kérek egy kávét és két zsömlét. - Én is azt kérek. Hiszen nem is igen tudnánk megmondani, mi is lenne az egy kávé és két zsömle szerkezet partitívuszos értelmezése. Az ugyanis nem életszerü, hogy ilyenkor a beszélő arra utal, hogy valahol tálcán elkészítve ott állnak az egy kávéból és két zsömléből álló fogások, és mi azok közül kérünk egyet.

Ez az utóbbi jelenség általánosabban megfogalmazva arra utal, hogy a vizsgált jelenség (vagyis az, hogy a mutató névmásokat határozatlan névszói szerkezetként is használjuk) semmilyen szempontból nem általánosítható: sem szintagmatikus szempontból (más szerkezetekben), sem pedig paradigmatikusan (más hasonló kifejezéseket vizsgálva). Mert igaz ugyan, hogy nemcsak tárgyként, hanem például egzisztenciális szerkezetek alanyaként is megjelennek mutató névmások (pl. Van benne ez/az is 'tartalmaz ilyet/olyat is', Ez/Az van benne 'ilyet/olyat tartalmaz'), ami arra utal, hogy ilyenkor is viselkedhetnek határozatlan névszói szerkezetként, de a 
bővítményi szerepeken kívül más határozatlan („puszta”, „predikatív”) névszói szerepeket nem tud betölteni a mutató névmás (nem nagyon hallani például olyat, hogy ${ }^{\star}$ ezem/ ${ }^{*}$ azom 'ilyenem/olyanom'). ${ }^{\star} H a ́ n y /{ }^{*} M e n n y i ~ e z / a z$ van benne? Ami pedig a paradigmatikus tengelyt illeti, nem állja meg a helyét, hogy akár csak úgy általában a demonstratívok képesek lennének „fajtára utalni” vagy „partitívuszi jelentést hordozni”, és így határozatlanként viselkedni. Magyartalannak érezném az olyan szerkezeteket, mint * Ezt/Azt a szószt is rakj bele ('ilyen/olyan szószt') vagy *Ezt/azt a festéket kent rá ('ilyen/olyan festéket').

Összefoglalva: az ez, az mutató névmások sajátos viselkedését nem érdemes, mert nem is lehet általános elvekből levezetni, nem terjed ki más mutató elemekre és más mondattani környezetekre, hanem csak a Simonyi által megfigyelt szerkezetekben érvényesül (amikor önállóan igei bővítményként szerepelnek). Ez legalábbis ennek a példának az esetében ellentmond a maximális általánosítások stratégiájának, és a „naiv fizika” mintájára a „naiv szemantika” (ill. „naiv nyelvtan”) mellett szól, miszerint sok partikuláris, nem általánosítható ismeret-darabból áll össze a tudásunk (ebben az esetben: a nyelvtudásunk), még ha ez az ismeret-készlet gazdagon be van is hálózva asszociatív kapcsolatokkal (ezek a kapcsolatok kifejezhetnek hasonlóságot, együttes előfordulást, gátlást stb.).

\section{Naiv nyelvtan}

A 20. század második felének nyelvészete tobzódott a szabályrendszerekben, és annak érdekében, hogy a lehető legszükebb szabályrendszert kelljen feltételezni, igyekeztek a lehető legáltalánosabb szabályokat megfogalmazni. Különösen jellemző ez a Chomsky (1957) által megindított generativista iskolában. Ugyanakkor azt tapasztalom, hogy az ebben az időszakban szinte minden nyelvész által elfogadott hiper-általános kategóriák (mint amilyen például a szerkezetek „feje”, vagyis az az eleme, ami állítólag a legjellegzetesebb tulajdonságait hordozza, bármit jelentsen is ez, akár ténylegesen jelen van, akár nem) a levezetések és ábrázolások hihetetlen bonyolultságához vezettek, például rengeteg „absztrakt” (vagyis közvetlenül nem megfigyelhető) elem és szerkezet feltételezésével kell fizetni az általánosságért.

Azt a megközelítést nevezem naiv nyelvtannak, amelyik mintegy „naiv” módon tekint a nyelvi jelenségekre, mintha nem is tudna arról, hogy bizonyos külső (a nyelvtudományon kívül álló) megfontolások szerint arra kellene kényszert éreznie, hogy minél általánosabb törvényszerüségekből vezesse le őket. Ezt az elnevezést tehát az összefoglaló neveként használom mindazoknak az irányzatoknak, amelyek csak az induktív általánosításokat fogadják el megengedhető absztrakcióként. Ilyen iskolák például a konstrukciós nyelvtan különböző változatai (I. Kálmán 2001) vagy a használatalapú nyelvtan (I. Diessel 2015).

Ezeknek a nyelvtanoknak (vagyis összefoglaló néven: a naiv nyelvtannak) az a közös sajátosságuk, hogy a különböző kifejezéseknek, szerkezeteknek csak a felszíni (formai és funkcionális) hasonlóságait veszik számításba. A visszatérő és a kifejezések megkülönböztetésében szerepet játszó hasonlóságok (asszociatív) kapcsolatokat teremtenek a kifejezések között, és így a nyelvtan egy hálózat formáját ölti. A hálózat-jellegnek az a jelentősége, hogy a tényleges nyelvhasználatban tapasztaltak magyarázatát mindig a hálózatban már létező kapcsolatokra kell alapozni. Az új kifejezések megalkotása és megértése mindig a létező (a hálózatban 
szereplő) kifejezések mintájára (analógiájára) történik, és mindig a tárolt, megjegyzett kifejezéstípusoknak azok a részei játszanak ebben szerepet, amelyek hasonlósági kapcsolatban, összeköttetésben állnak más tárolt kifejezéstípusokkal (ennek részletes mechanizmusáról ld. pl. Guzmán Naranjo (2019)). (A kapcsolatoknak egy másik típusa is létezik, ami nem a hasonlóságoknak, hanem az együttjárásoknak köszönhető, erről itt most csak implicite lesz szó. Hiszen már eleve azért beszélhetünk egy-egy kifejezéstípusról, mert visszatérően együttjáró elemek alkotják őket.)

Egyetlen egyszerü példával szeretném ezt megvilágítani. Vegyünk egy olyan névszói szerkezetet, mint a minden osztály legmagasabb tanulója. A nagyon általános szófaji és mondattani kategóriák használatával ezt úgy jellemezhetjük, hogy birtokos szerkezetről van szó, amiben a birtokos szerepét a minden osztály, a birtok szerepét pedig a legmagasabb tanulója játssza. A birtok az alaptag (a szerkezet feje), a birtokos egyfajta módosító vagy determináns. A birtokoson belül az osztály az alaptag, a minden pedig egy determináns (közelebbröl mennyiségjelölö, kvantor), míg a birtokon belül a tanulója az alaptag, ennek a módosítója vagy determinánsa a legmagasabb.

Különböző mondattani és jelentéstani megfontolások alapján azonban ezt az iskolai nyelvtanból ismerős elemzést sok szempontból bonyolítani kell (egy lehetséges modern elemzést ad Bos (2009)). Először is a modern nyelvtanok megkülönböztetik a módosítókat a determinánsoktól, a módosítók ugyanis mindig elhagyhatók, és jelentéstanilag csak szükítik az alaptag által kijelölt dolgok körét, márpedig sem a minden, sem a legmagasabb, sem maga az egész birtokos, a minden osztály nem jellemezhetők úgy, hogy ebben az értelemben az osztály, a tanuló, illetve a legmagasabb tanuló módosítói lennének. A determinánsoknak egészen más a szerepük, és sok modern elméletben őket tekintik a szerkezetek alaptagjának. Hiszen például ha a minden gyerek egy mondat alanyának a szerepét tölti be, akkor a minden determináns hatására az egész mondat univerzális értelmet kap. Tehát jelentéstanilag mintha nem is csak az alany, hanem az egész mondat fő operátoraként viselkedne.

Ha tehát azt szeretnénk, hogy a mondattani szerkezet hüen tükrözze az állítás jelentéstani szerkezetét (vagyis hogy az ún. kompozicionalitás alapelvének meg akarunk felelni, ld. alább), akkor a szerkezeti elemzést meg kell bonyolítanunk. Amikor a minden gyerek szerkezet az alany, akkor a minden egyszerre játssza ebben a szerkezetben a determináns szerepét, és ugyanakkor egy másik szinten (vagy a levezetés egy másik lépésében) az egész mondat szerkezetében a fő operátor szerepét játssza. Ennek megfelelően a vizsgált birtokos szerkezet esetében háromszoros szerepet is játszik a minden, mert egyrészt a birtokoson belül (minden osztály) a determináns szerepét játssza, ugyanakkor az egész birtokos szerkezetet is univerzálissá teszi (hiszen a minden osztály legmagasabb tanulója egy bizonyos módon kiválasztott tanulók mindegyikére utal, mintha minden tanuló-t mondanánk), harmadszor pedig a minden - a minden gyerek esetéhez hasonlóan az egész mondatot is univerzálissá teszi, tehát valamilyen absztrakt értelemben, a levezetés valamely pontján neki kell a mondat egyik fő összetevőjének, operátorának a szerepét játszania.

Hasonló bonyodalmakat okoz a legmagasabb szerepe a birtokon (legmagasabb tanulója) belül. Ha jelentéstanilag úgy tekintenénk, hogy az a szerepe, hogy az alaptag által jelölt sokaságból kiválasztja a legmagasabbat, akkor a legmagasabb 
tanuló kifejezés értelmezése egyetlen tanuló lenne, amelyik (a tanulók valamilyen, talán a kontextusból kitalálható körén belül) a legmagasabb. Csakhogy az egész birtokos szerkezet értelmezésében ennek nem sok hasznát vesszük, hiszen nem egyetlen tanulót kell kiválasztani. A birtokos (minden osztály) határozza ugyanis meg, hogy a tanulók milyen körének (sőt köreinek) a testmagasságát kell megmérnünk, és a legmagasabbakat ennek megfelelően kiválasztanunk. Vagyis a birtokos értelmezése befolyásolja a birtok értelmezését, ami ellentmond annak, hogy a birtok az alaptag. Másképpen mondva: jelentéstanilag a legmagasabb nem magán a birtokon (legmagasabb tanulója) belül játszik szerepet, hanem mintha egy absztrakt (közvetlenül nem megfigyelhető) birtokos szerkezet, az osztály tanulója jelentésére kellene alkalmazni az ő jelentését (ami ugyebár a legmagasabb elem kiválasztása). Végül pedig a minden szó jelentése az ilyen módon kiválasztott tanulók összességére vonatkozik. Nem vállalkoznék rá, hogy lerajzoljam az így kialakuló, kissé összegubancolódott szerkezetet, de informálisan talán így lehetne jellemezni: „a mondat minden olyan egyénről állít valamit (mindegyikről ugyanazt), amelyik a legmagasabb valamelyik osztálynak a tanulói közül”.

Ezek a bonyodalmak akkor állnak elő, és akkor vezetnek ahhoz, hogy a leírásba természetellenes, ad hoc, független érvekkel nem alátámasztható eszközöket kelljen bevezetni, ha a maximális általánosságra való törekvést nemcsak az egyes szavak jelentésére alkalmazzuk (ld. a már, még, is, ez/az példáját feljebb), hanem a szerkezetek felépítésére és értelmezésére is. Valójában semmiből sem következik, hogy minden determinánsos szerkezetet egyformán kelljen kezelni és értelmezni, függetlenül attól, hogy a determináns névelő-e, mennyiségjelölő, felsőfokú melléknévféle vagy akár birtokos (ha az egyáltalán determináns, nem pedig módosító), sőt, még ezeken a determinánsfajtákon belül sem kell homogeneitást feltételezni. És például az sem következik semmiből, hogy a mennyiségjelölőket egyformán kell kezelni akkor, amikor közvetlenül egy bővítményhez kapcsolódnak, és amikor egy birtokos szerkezetben a birtokhoz. Mindezek a feltételezések kizárólag a maximális általánosságra való törekvés következményei, bár a „következmény” talán kicsit túlzó kifejezés is, hiszen az általánosítások maximalizálásának elvéből az nem következik, hogy pontosan milyen jelenségeket kell egyetlen általánosításba összevonni.

Azt hiszem, ezek után világos, hogy a fent már bevezetett „naiv nyelvtannak” miben áll az alternatív megoldása. Azokat és csak azokat a szerkezettípusokat kell egységesen kezelni, amelyeknek valóban egységes a felépítésük és az értelmezésük, és csak annyiban szabad őket egységesen kezelni, amennyiben ezt az egységességi feltételt kielégítik. Lehet, hogy egy-egy nyelv leírásában ezért nagyon sokféle szerkezettípust kell feltételezni (még ha ezek mindenféle asszociatív kapcsolatban állnak is egymással), de semmi bizonyíték sincs arra, hogy az így kapott rendszer bármiféle mérőszám szerint bonyolultabb lenne, mint a túlzott általánosításokból származó bonyolultság. Ezt a szemléletet a modern nyelvészetben (főleg pedig a jelentéstanban) csak nagyon kevesen képviselik, de például ez az egyik alapelve az ún. konstrukciós nyelvtannak (ennek első klasszikus dokumentuma FillmoreKay-O’Connor (1988); a szemantikára alkalmazva I. Kálmán (2018)).

Kerültem ebben a megfogalmazásban a szabály szó említését (mondhattam volna úgy is, hogy nagyon sok specifikus „szabályra” van szükség), mert a szabályok fogalma túlságosan kapcsolódik a levezetések fogalmához, a levezetések pedig arra szoktak szolgálni, hogy nagyon általános, absztrakt entitásokból vezessük le 
konkrét szerkezetek, jelentések, jelenségek létezését. Ha viszont nem az általánosításokra helyezzük a hangsúlyt, akkor a szabály szó helyett egyszerűen szerkezettípusoknak és értelmezésüknek a leírásáról érdemes beszélni (és persze az ezek közötti kapcsolatok leírásáról).

Ennek szellemében a minden osztály legmagasabb diákja szerkezettel kapcsolatban elsősorban azt kell megjegyeznünk, hogy a birtokos szerkezeteknek nagyon sok fajtájuk van, például a birtokos és a birtok kapcsolatát illetően, köztük az, ami az osztály diákja-jellegüekben megnyilvánul (ahol a viszony az, hogy 'a birtok a birtokossal jelölt csoporthoz, helyhez stb. tartozik'), vagy például aszerint, hogy a birtokos egyetlen dologra utal-e, vagy pedig valamilyen sokaságra. A sokaságokra utaló birtok esetén további különbségtétel, hogy a szándékolt értelmezés szerint a birtok közösen, kollektíve kapcsolódik-e a birtokoshoz, vagy egyenként, disztributíve. Valószínúleg még a sokaságra utaló birtokot tartalmazók sem viselkednek teljesen egységesen, mert eltérhet a többes számú és a mennyiségjelölös birtokosok viselkedése - például a minden-es birtokosoknál erősen preferált a disztributív olvasat, kivéve olyan egészen sajátos szerkezeteket, mint a minden oroszok cárja, ami már az oroszok többes számú alakja miatt is kivételes, és nyilvánvalóan memorizálandó, ha nem is szóról-szóra.

Ennek ellenére a birtokos szerkezetek természetesen egy csomó általános vonásban osztozhatnak (bár alcsoportonként eltérhet, hogy pontosan milyen vonásokban), és az ilyen tényleges közös vonások persze indokolják az általánosítást. Például azok a tények, amik a birtokos és a birtok toldalékolására vonatkoznak, ki lehet mondani általánosításként (bár, mint tudjuk, ez sem egyetlen általánosítás lesz, hiszen a magyarban van toldalékkal jelölt és jelöletlen birtokos, és toldalékkal jelölt és jelöletlen birtok, és ezek nagyon eltérő szerkezetekben fordulnak elö). De ilyenkor az általánosítás (amit a leírt szerkezettípusok közötti asszociatív kapcsolatokkal fejezhetünk ki) csak ezekre a közös (ebben az esetben formai) tulajdonságokra vonatkozik, és nem feltétlenül mond bármit is arról, hogy az illető szerkezetek más tulajdonságai mennyiben hasonlítanak egymásra. Ezért ügyeltem arra a fentiekben, hogy csak a „túláltalánosítást” kérdőjelezzem meg.

Sajnos vagy nem sajnos, de úgy néz ki, hogy a felsőfokú determinánst tartalmazó birtokokat is önálló szerkezettípusnak kell tekintenünk, amiatt a sajátos értelmezése miatt, amit a minden osztály legmagasabb tanulója esetében láttunk. Az uralkodó nyelvészeti hagyomány miatt tűnhet „pazarlónak” az ilyen sajátos szerkezet feltételezése, de más érv nemigen szólhat ellene. „Gazdaságtalannak” tűnhet, de ezt csak úgy lehetne igazolni, ha számszerűsíteni tudnánk, hogy „gazdaságosabb” lenne egy több lépésből álló, absztrakt jelentéseket és szerkezeteket is feltételező leírás. De jelenlegi tudásunk szerint nincs lehetőség ilyen számszerüsítésre.

\section{Naiv szemantika és kompozicionalitás}

A modern nyelvészet fő irányzatai nemcsak a maximális általánosításra való törekvésük miatt ódzkodnak a naiv nyelvtantól és szemantikától, hanem azért is, mert sajátosan értelmezik a kompozicionalitásnak nevezett módszertani alapelvet. A kompozicionalitás elvét többféleképpen kimondták már, a legáltalánosabb formája, amit sokan Boole-nak (1854) tulajdonítanak, az, hogy egy összetett kifejezés jelentése nem függhet mástól, mint a részeinek a jelentésétól, valamint attól, hogy ezek a 
részek milyen szerkezetet alkotnak. (Az elv legprecízebb megfogalmazása Montague (1970)-ben található.) Ennek az elvnek (legalábbis ebben a formájában) valószínűleg ellentmond a fenti naiv nyelvtani elképzelés, hiszen abban feltételeztem, hogy például a már, még, is szavak tagadott környezetben egészen mást jelentenek, mint álítóban, vagy hogy a determinánsoknak esetleg más-más jelentést kell tulajdonítanunk más-más szerkezetekben (például attól függően, hogy birtokosnak, birtoknak vagy más értelmű névszói szerkezetnek a determinánsa-e). Hasonlóképpen a fent említett konstrukciós nyelvtani irányzat is kénytelen eltérni a kompozicionalitás Montague-féle meghatározásától (I. Kay-Michaelis 2012).

A jelentés szót azért emeltem ki a meghatározásban, mert fontos, hogy az elv nem a kifejezések értelmezéséról szól, mert az egész szerkezet értelmezése bizony sok minden mástól is függhet, mint a részek jelentése (elsősorban az elhangzás körülményeire kell gondolni: az én szó más és más személyre utal attól függően, hogy ki a beszélö), a részek értelmezése pedig sokszor lehetetlen is az egész szerkezet ismerete nélkül. Az én személyes véleményem szerint a kompozicionalitás elvének ez az egészen általános formája inkább arról szól, hogy aki ezt az elvet vallja, az mit is ért pontosan jelentésen (ti. olyasvalamit, ami engedelmeskedik ennek az elvnek), nem pedig arról, hogy hogyan is kell egy nyelv formai és jelentéstani vonásait leírni.

Röviden összefoglalva: aki a kompozicionalitásnak ezt az elvét elfogadja, az a jelentés terminusnak azt a (nagyon általánosan elfogadott) értelmezését választja ezzel, hogy a szavak (és/vagy a szerkezetek) jelentése olyan információ, amit ezek a környezetüktól függetlenül hordoznak, a környezet szóba itt beleértve az elhangzás körülményeitöl egészen addig, hogy milyen nagyobb szerkezet részeként fordul elő az illető nyelvi egység.

De vegyük észre, hogy a jelentés szónak ez az értelmezése végső soron éppen az, amit az 1. alpontban túl általánosnak értékeltem. Abban az alpontban éppen arról volt szó, hogy például a már, még, is stb. szavaknak nyilvánvalóan reménytelen olyan absztrakt „,jelentéseket” tulajdonítani, amelyek olyan általánosak, hogy minden egyes konkrét előfordulásukban megfigyelhetők, vagy legalábbis minden esetben le lehet belölük vezetni az éppen szükséges értelmezésüket.

Így tehát igazuk van azoknak, akik aggódnak, hogy a naiv szemantikában a kompozicionalitásnak ez a leghagyományosabb megfogalmazása nem érvényesülhet, hiszen nem fér össze a naiv szemantika alapelveivel. A naiv szemantikában ugyanis könnyen előfordulhat, hogy egy bizonyos szó (vagy más nyelvi elem) jelenléte egy bizonyos szerkezetben egészen más funkcióval jár együtt, mint ugyanannak a szónak (elemnek) egy másik szerkezetben való megjelenése, ahogy ezt a már, még és is szavakkal kapcsolatban jeleztem.

A naiv szemantikában elsősorban egy egész szerkezettípushoz tartozik ,jelentés” (pontosabban értelmezési minta), és csak ennek járulékos következménye, ha az ilyen szerkezetekben (a szerkezettípus által előírt módon) szereplő szavak értelmezésére ezt „rávetítjük”. Így például a már említett már-ral bevezetett kérdések önálló szerkezettípust (ún. konstrukciót) képviselnek, amelyeknek a használatát egészükben kell jellemezni, és ha valaki bizonyos mértékig motiváltnak tartja, hogy a magyarban ez a használat éppen a már megjelenéséhez van kötve, akkor ennek a szerkezettípusnak a használatába „beleérezheti” a már egy bizonyos értelmezését. De arról szó sincs, és az általam naiv nyelvtannak és naiv szemantikának nevezett 
megközelítésbe nem is fér bele, hogy magának a szerkezettípusnak a létezését abból vezessük le, hogy a már-nak sok más között egy ilyenfajta ,jelentést” is tulajdonítunk. Ezért a naiv szemantikában a kompozicionalitás elve csak annyit jelenthet, hogy minden kifejezés értelmezésének alkalmazkodnia kell a kifejezésben megtestesülő konstrukciók értelmezési mintáihoz.

\section{Köszönetnyilvánítás}

Köszönöm Lagos Mátyásnak az írás vázlatához füzött megjegyzéseit.

\section{Hivatkozások}

Arisztotelész 1979. Hermeneutika. Organon. Budapest: Akadémiai Kiadó.

Boole, George 1854. An Investigation of the Laws of Thought: On Which are

Founded the Mathematical Theories of Logic and Probabilities. London:

Walton and Maberly.

Bos, Johan 2009. Computing genitive superlatives. In Harry Bunt - Volha

Petukhova - Sander Wubben (szerk.) Proceedings of the 8th International

Conference on Computational Semantics - IWCS-8 '09. Tilburg: Association

for Computational Linguistics. 18-32. doi:10.3115/1693756.1693763.

Chomsky, Noam 1957. Syntactic Structures. Hága: Walter de Gruyter.

Diessel, Holger 2015. Usage-based construction grammar. In Ewa Dąbrowska -

Dagmar Divjak (szerk.) Handbook of Cognitive Linguistics. Berlin: De Gruyter

Mouton. 295-321. doi:10.1515/9783110292022-015.

Fillmore, Charles J. - Paul Kay - Mary Catherine O'Connor 1988. Regularity and idiomaticity in grammatical constructions: The case of let alone. Language

64/3:501-538. doi:10.2307/414531.

Frege, Gottlob 1892. Über Sinn und Bedeutung. Zeitschrift für Philosophie und philosophische Kritik 100:25-50.

Friedman, Michael 1974. Explanation and scientific understanding. The Journal of Philosophy 71/1:5-19. doi:10.2307/2024924.

Guzmán Naranjo, Matías 2019. Analogical Classification in Formal Grammar.

(Empirically Oriented Theoretical Morphology and Syntax 5) Berlin: Language Science Press.

Hayes, Patrick 1979. The naive physics manifesto. In Donald Michie (szerk.) Expert Systems in the Micro-Electronic Age. Edinburgh: Edinburgh University Press. 242-270.

Kálmán László 2001. Konstrukciós nyelvtan. (Segédkönyvek a nyelvészet tanulmányozásához 8) Budapest: Tinta Könyvkiadó.

Kálmán, László 2018. Neo-Lockean semantics. In Huba Bartos - Marcel den Dikken - Zoltán Bánréti - Tamás Váradi (szerk.) Boundaries Crossed, at the Interfaces of Morphosyntax, Phonology, Pragmatics and Semantics. Cham: Springer International Publishing. 213-226. doi:10.1007/978-3-319-90710-9_14.

Kay, Paul - Laura A. Michaelis 2012. Constructional meaning and compositionality. In Claudia Maienborn - Klaus von Heusinger - Paul Portner (szerk.) Semantics. An International Handbook of Natural Language Meaning. Vol. 3 Berlin, Boston: De Gruyter Mouton. 2271-2296. 
Krifka, Manfred 2000. Alternatives for aspectual particles: Semantics of still and already. Annual Meeting of the Berkeley Linguistics Society 26/1:401-412. doi:10.3765/bls.v26i1.1125.

Montague, Richard 1970. Universal grammar. Theoria 36/3:373-398. doi:10.1111/j.1755-2567.1970.tb00434.x.

Paul, Hermann 1886. Principien der Sprachgeschichte. Halle: Max Niemeyer. Simonyi Zsigmond 1905 [1889]. A magyar nyelv. Budapest: Athenaeum.

Zimmermann, Malte 2018. Wird Schon Stimmen! A degree operator analysis of schon. Journal of Semantics 35/4:687-739. doi:10.1093/jos/ffy010.

\section{A szerzőről}

Kálmán László mintegy harminc éve a Nyelvtudományi Intézet kutatója és az MTA-ELTE Elméleti Nyelvészet Kihelyezett Tanszék oktatója. Ez alatt az idő alatt két évig tanított az Amszterdami Egyetemen is, és két évig dolgozott a versenyszférában is, a Mindmaker Ltd. nevü cégnél, amelyik a mesterséges intelligencia kutatásával foglalkozott. Fő kutatási területei a nyelvtanelmélet, a formális szemantika és a számítógépes nyelvészet. Jelentős a munkássága az iskolai nyelvi nevelés megreformálásában és taneszközök készítésében, valamint rendszeresen foglalkozik tudományos ismeretterjesztéssel.

Elérhetősége: kalman.laszlo@nytud.mta.hu 